\title{
Procedure for Obtaining a Certificate of Title to the Land in the Semarang: Case Study in the National Land Agency Semarang
}

\author{
Niken Windy Ika Pratiwi ${ }^{1}$, Munawwarah ${ }^{2}$ and Munsharif Abdul \\ Chalim $^{3}$
}

Abstract. The background of this thesis-making by the problems that occur in the community, where people are still not or do not understand the procedures milik. Terbukti acquire rights to their land dispute or a state-owned building that happened because the people who inhabit this land are not applying for property rights and feel that the land itself. Scription this is made so that people understand about the procedures for securing property rights. Results: (1) Procedures of obtaining the certificate is property rights on state land through the National Land Agency, is generally set in the norm of the Minister of Agriculture No. 9 of 1999 on Procedures for Granting and Cancellation of State Land Property Rights and Rights Management. In Article 19 paragraph (2) BAL consisting of: bookkeeping land, registration of property rights, transfer of land rights, granting letters of proof of receipt of rights, (2) Barriers and solusiyang arising from applicant in the application process right (external): lack of accessories the proposed requirements of the applicant, not terselesainya application fee, the land dispute would be applied. Barriers arising from the Office of the (internal): lack of personnel in the service of the applicant carefully situations, employees who lack discipline, negligence of officers in performing their duties. Solution resistance of the applicant (external): more thoroughly before entering the application requirements, before making an application should first ask for details of funds in the process of granting the right, please check whether the land is in sengeketa or not. Solution barriers of Office (internal): officers should be more responsible in performing their duties, and provide a deterrent effect to employees who are lazy in performing their duties.

Keywords: Procedures; Certificate of Property Rights; State land.

\section{Introduction}

Land for human life is very important. The land itself is indispensable to human life. Moreover, the composition of the Republic of Indonesia including the lives of its people especially still patterned agrarian economy, which is predominantly farming and cropping get results from it.

The provisions of the basic land in Indonesia has been listed in Act No. 5 of the Basic Regulation tahun1960 Agrarian, better known as the Basic Agrarian Law, which includes the main points of the Indonesian National Land Law. Although most of the chapters provide provisions concerning rights to land, but as a provision that is the subject of much material that is more detailed settings that still need to be specified. ${ }^{2}$

State power shall include all the land within the territory of the Republic of Indonesia, both lands that are not yet or are already dihaki with individual rights in the BAL are

\footnotetext{
${ }^{1}$ Master of Notary Students, Faculty of Law UNISSULA, email nikenwindyip28@gmail.com

2 Students of Master of Law, Faculty Of Law, Universitas Islam Sultan Agung email ara41ah@gmail.com

${ }^{3}$ Lecturer Master of Notary UNISSULA, Semarang

${ }^{2}$ Indonesia legal Center Publishing, Hak-hak Atas Tanah,Jakarta,2013
} 
called lands directly controlled by the State, which in Land Administration is shortened to ground The land of the State. ${ }^{4}$

Based on the master right then, in Article 4 paragraph (1) BAL is determined that there are variety of land rights under Article 18 of the BAL itemized as follows:

- Right of ownership

- Cultivation Rights

- Building rights

- rental rights

- Right to life

- Right to unlock the Land

- Usufruct of forest

- Other rights are not included in these rights.

And one of them is the right to land ownership, diaman in Article 8 (1) every citizen has equal opportunity to obtain land titles. While the acquisition of property rights itself according to customary law is regulated by the Government, other than ownership can be obtained by:

- Determination of the government

- Statutory provision

Thus the acquisition of property rights to be determined by the government, by way of acquisition of property rights by submitting an application to the authorities. Acquisition of property rights based on the determination of the government can be described as a way of obtaining property through a rights request. This means that the government give land titles that are directly controlled by the State, based on a petition rights.

Granting of land by the State through the way in which a person or legal entity first apply. The petition is a process that starts from the entry application to the National Land Agency until the birth of tenure, which requested it. The series of the process will involve land that would be asked of the applicant, the right to request, how the petition was underway, the agency reserves the right to accept the petition is authorized to issue a decision denied / granted the petition in question, and everything must be considered and carried out to the applicant obtain proof (certificate) gets land rights. To obtain the certificate of the applicant after obtaining decree of the authorized agencies and registering the land rights.

Under PP. 24 of 1997 on Land Registration. This will result in a letter given proof of rights to land, commonly called land certificate to the applicant applies as a strong evidence for the right to land was holding it and ensure legal certainty. In accordance with the purpose of establishing the BAL is laying the groundwork to provide legal certainty regarding the rights to the land for the people. So with the implementation of the objectives mentioned above means in accordance with the contents specified in Article 19 paragraph (1) BAL, which reads:

- To ensure legal kepatian government held land registration throughout the territory of the Republic of Indonesia in accordance with provisions stipulated by Government Regulation

- The Land Registry in paragraph 1 of this Article shall include: Measurement, spotting and bookkeeping Land; Registration of rights to land and transfer of such rights; and Award letters proof of rights, which serves as a strong evidentiary tool.

Such a policy may be a political reality with the issuance of PP. 24 of 1997.

Based on the description in the above background, the issues that will be analyzed are as follows: What is the procedure obtain a certificate of title for the land the state in

\footnotetext{
${ }^{4}$ Boedi Harsono, Hukum Agraria Indonesia, Jilid I, Djambatan, Jakarta, 1994, p. 121
} 
Volume 6 Issue 2, June 2019

Semarang?, Barriers anything arising in the procedure of obtaining a certificate of property rights on state land in the Semarang and how the solution?

\section{Research Methods}

This study is a descriptive analysis. This type of research is juridical sociology. The data used in this study are: Primary and secondary Legal Materials

The method used is qualitative analysis, namely data obtained through fieldwork and research literature then arranged systematically, and then analyzed qualitatively to achieve clarity issues to be discussed. The data is then analyzed using a theoretical and interpretive positive law which has been poured and then deductively conclude to address existing problems. ${ }^{4}$

\section{Results And Discussion}

\subsection{Procedure Obtaining Property Rights on State land in Semarang District}

Procedures of obtaining the certificate on the State Land Property Rights in the District Land Office of Semarang, in general stipulated in Minister of State for Agrarian Affairs / Head of National Land Agency No. 9 of 1999 on Procedures for Granting and Cancellation of State Land Property Rights and Rights Management.

Based on Government Regulation No. 24 of 1997 on land registration, land registry is a series of activities carried out by the Government continuously, continuous and regular, covering the collection, processing, bookkeeping and presentation, as well as the maintenance of physical data and juridical, in the form of maps and lists, on parcels of land, and apartment units, including the granting of rights letter of receipt for parcels of land that the existing rights and ownership of units tumah stacking and certain rights which encumber.

Objects Land Registry include:

- Parcels of land that belongs to property, the right to cultivate, building rights and rights of use

- Land management rights

- Waqf land

- The ownership of the apartment units

- Mortgage right

- Ground state

\subsubsection{Land Registry Services in First Time}

Admission requirements Affirmation Rights:

- The application form was completed and signed by the applicant or their proxies enough on stamp duty

- The power of attorney if authorized

- Copy of identity (ID card, KK) the applicant or their proxies if authorized, which has been matched to the originals by the counter clerk

\footnotetext{
${ }^{4}$ Wawan Muhwan Hariri, 2011, Hukum Perikatan Dilengkapi Hukum Perikatan Dalam Islam, Pustaka Setia, Bandung, p.85
} 
- Proof of ownership of the land / property rights of indigenous pedestal / used to belong to indigenous

- A copy of the UN SPPT current year which has been matched to the originals by the clerk and the submission of evidence SSB (BPHTB)

- Attach proof of SSP / Income in accordance with the provisions of

The registration fee in accordance with the provisions of Government Regulation on types and tariffs on the type of non-tax revenue in force at the National Land Agency of the Republic of Indonesia. The first time signup fee is Rp. 25,000 with a time of execution 98 days.

The terms of application for property rights as follows: (1) An Indonesian citizen; (2) bodies the law established by the Government in accordance with the provisions of the applicable regulations are: Bank of Government, Religious Bodies and Social Centers designated by the government. Since the granting of property rights to a legal entity can only be granted on certain lands.

In accordance with the provisions of Regulation of the Minister of Agrarian Affairs / Head of National Land Agency No. 9 of 1999, a request for property rights must be taken as follows: Type of property rights can be done in writing, Request property rights to land include:

- Information about applicants

- If applicant is individual: name, address, nationality and occupation, information the wife / husband and children who are still dependents.

- If the petitioner is a legal entity: name, place, position, acts or regulations pemdirinya, date, number endorsement by an official decree that authorized on the appointment as a legal entity that can have property rights based legislation.

- Description of the land that includes juridical and physical data:

- Basic mastery of the form of certificates, girik, plots letter, a letter of release and the letter of the land settlement, court decisions, PPAT deed.

- Letas, boundaries and extent (if any measurement certificate or picture the situation mentioned dates and number)

- Type of soil

- Land use plan

- Status of the land (state land or land rights)

\subsubsection{Terms of Granting Rights Reserved}

Terms Granting of Individual Property Rights include:

- Registration form filled out and signed by the applicant or their proxies enough on stamp duty

- The power of attorney if authorized

- Copy of identity (ID card, KK) the applicant or their proxies who have been matched with the original by the counter clerk

- First evidence of land acquisition

- The original letters and proof of a debt waiver and home (home goal III) or a house bought from the government

- A copy of the UN SPPT current year which has been matched to the originals by the clerk, submission of evidence SSB (BPHTB) and proof of payment of money income (cash register)

- Attach proof of SSP / Income in accordance with the provisions of

Individual Property Rights The application form contains:

- Personal identity 
Volume 6 Issue 2, June 2019

- Size, location and use of the land requested

- The statement that the land is not in dispute

- Statement physically occupied land

- Statement mastering no more than 5 fields in the application for residence

Note:

- Not including a grace period of fulfillment of payment obligations in accordance SK

- Duration does not include the time required for the purposes of sending files / documents from Kantah to the Regional Office and BPN RI and vice versa

Execution time:

- 38 days for large farms of no more than 2 ha and non-agricultural land no larger than $2,000 \mathrm{~m}^{2}$

- 57 days for large farms of more than 2 ha daan non-agricultural land area of more than 2,000 $\mathrm{m} 2$ and 5,000 $\mathrm{m}^{2}$

- 97 days for non-agricultural land covering an area of over 5,000 $\mathrm{m}^{2}$

Registration fee:

In accordance with the provisions of Government Regulation on the type and state revenue tax rates in effect at the National Land Agency of the Republic of Indonesia.

Terms Granting Legal Entity Properties include:

- The application form was completed and signed by the applicant or their proxies enough on stamp duty

- The power of attorney if authorized

- Copy of identity (ID card, KK) if authorized applicants or their proxies who have been matched with the original by the counter clerk

- Copy Akya establishment and Validation Legal Entity that has been matched to the originals by the counter clerk

- Evidence landright

- SK Appointment of Legal Entities can be obtained Hak of the National Land Agency

- A permit to obtain the Property Right of the National Land Agency

- A copy of the UN SPPT current year which has been matched to the original by counter with additional officer SSP / Income in accordance with the provisions of

\subsubsection{The process of handling and administration of Property Rights on State Land}

After all the specified requirement been completed by the applicants both applicant individuals and applicant legal entities, the file submitted to the Land Office.

From the description above, a description of the procedures for granting property rights on state land, as follows:

- Services In Counters 1

For applicants who do not know tat events or procedures regarding the request with the land papers were sober, and new sign land office Semarang, then on counter 1 petition explained on the petition referred to by the applicant, then provided guidance regarding the form and under what conditions the needed for the petition. After that applicants are welcome to counter II

- Service At Loket II

On the counter II is part of the ministry of blanks, where applicants are required to fill in the blank in accordance with the existing provisions with a complete and clear, the next should be handed to the counter II (part verification and acceptance of the applicant's file). 
- Service At Loket III

After getting the details of fees and signature, then submitted to the applicant to come to the counter III (special treasury receiver section) in order to pay the necessary costs. Once the files are grouped by officers in accordance with the particular type of request, enclosing the payment marks left on the counter II.

After all the file is deemed complete, the head of the land see whether or not the file is further processed in accordance with the regulations. Then notify the applicant to pay the cost of completion of the request that has been ruled by law.

If in terms of land measuring no letter, the head of the land agency sent the chairman of the land for make and registrate measurement certificate that is a necessary plot situation.

- Service At Loket IV.

After a specified time, the applicant can take the land rights certificates specified in Loket I.

\subsubsection{Issuance of Certificate of Land}

Certificate as proof of the right letter, published in the interests of the relevant right holders, in accordance with the physical data and juridical data that has been submitted, along with the measurement certificate. Obtaining the certificate is the right of every holder of rights, in accordance with the already included in Article 31 of Government Regulation No. 24 of 1997 said that: The certificate was issued for the benefit of rights holders concerned in accordance with the physical data and juridical data which has been registered in the land book as referred to in Article 30 paragraph (1). Certificate Issuance intended that rights holders can easily prove its right. For the certificate is valid evidence in legal actions. ${ }^{61}$

\subsection{Obstacles and Solutions in the Face in the Procedure Obtaining Property Rights to State land in Semarang.}

In the implementation of the provision of property rights on state land, there are several obstacles that occur, either from the agency or from the land office and constraints that arise from the applicant itself.

In practice, we often get the barriers that come from the applicant or from the office. From the applicant's own obstacles arise because of lack accessory requirements needed in the petition that in wills, the number of unresolved charges, disputes over land being applied for. While the land office itself obstacles that arise due to lack of personnel carefully situations in the line of duty and negligence of officials. But of these shortcomings we strive to always improve the quality of work so that the public / applicants get better service. ${ }^{62}$

Hambatanya constraints, the authors differentiate into two (2) that the internal resistance and external barriers

The internal barriers Land Office consists of:

- Employees who lack discipline

- Employee negligence in performing their duties. ${ }^{64}$

\footnotetext{
${ }^{61}$ Results Interview with Mr. Dwi Agus as the Head of Land Rights in the Office of the National Land Agency of Semarang District dated January 22, 2018

62 Ibid.

${ }^{64}$ Ibid.
} 
Volume 6 Issue 2, June 2019

\subsubsection{Solution resistance of the Land Office (Internal):}

Delaying off any work that is normally done handled. In the case employees are lazy in carrying out this responsibility with regard to customs question. The employees who underestimate her job. The solution is to impose sanctions in the form of a written warning or sanction to employees, or sanctions in the form of a score, suspended or permanently, it aims to provide a deterrent to employees who are lazy and help them have a passion to work and continue to serve the community well. ${ }^{65}$

The constraints of external (applicant) consists of:

a. The lack of accessories necessary requirements in the application of data both physical and juridical data include: measurement certificate, a picture of the situation, the IMB. While the juridical data: girik letter, letter plots, PPAT deed, letter of waiver and debt repayment, court decisions, certificates pelapasan rights, and other land acquisition letter.

b. Unresolved application fees such as application fees the first time, the cost of measurement

c. A committee costs money

d. Disputes on land that would be applied. ${ }^{63}$

\subsubsection{Solution obstacles arising from the applicant (External):}

- The lack of data completeness juridical and physical data in the filing of the petition. So in this case the applicant must:

- To examine and re-examine the requirements that will be submitted to the clerk

- Noted in the information field

- Ask for a receipt in the file submission

- Provide juridical and physical to the clerk by mail notification We recommend that if the specified requirements have not been furnished by the applicant, the application file may be withheld in advance, and then when the file is fully furnished can file this continued. The avoid unwanted issues. ${ }^{64}$

- Output unresolved charges in the application process. Before making an application, prefer the applicant requested in advance details of funds expended in the process of granting land titles.

- Disputes of land petitioned

With regard to the case of land, the applicant is expected to check the ground who would be asked, if the land is experiencing a dispute, the land office can be a mediator in the settlement of the dispute. If the dispute can be resolved, the request can be processed and will be issued a certificate. ${ }^{65}$

\section{Closing}

\subsection{Conclusion}

- Procedure obtain a certificate of land ownership in the Semarang is the government's obligation in the registration of the land throughout the territory of

\footnotetext{
${ }^{65}$ Ibid.

${ }^{63}$ Ibid.

${ }^{64}$ Ibid.

${ }^{65}$ Results Interview with Mr. Dwi Agus as the Head of Land Rights in the Office of the National Land Agency of Semarang District dated January 22, 2018
} 
Indonesia through Indonesia Land Agency, in accordance with that stipulated in Article 19 paragraph (2) of the Basic Agrarian Law, this chapter includes:

- Surveying, mapping, soil bookkeeping

- Registration of land rights and land rights inbetween the

- Award letters proof of rights, which apply as much evidentiary evidence.

- Obstacles and solutions in obtaining the certificate of land ownership in the country of the Semarang District is due to internal factors and ektsternal. Barriers arising from the Office of the (internal) that employees are careless in the line of duty, and employees who lack discipline. Barriers arising from the applicant (external) that lack accessory application requirements, application fee has not been completed, and the dispute of land in pray for. Solution barriers of Office (internal) that provides for sanctions in the form of strikes, score, even dismissal if found negligent in performing their duties. Solution resistance of the applicant (external) that check the requirements before being handed to the clerk, asking for details of funding request for more details, check back in the land who would be asked.

Problems that arise in every process of acquisition of land ownership is a common problem as it occurs, be it problems arising from the land office and the problems arising from the applicant himself. In this case happened in the National Land Office of Semarang District, any problems the acquisition of property rights to land can be overcome with the counters that have their respective functions that make it easier for applicants to get the application submitted.

\subsection{Suggestion}

- for the Government; In the registration rights to the land, the applicant must pay attention and make sure whether the land object in trouble or not. Due to the existing dispute indicates that the weak system of registration of land that occurs either of law or of certain elements who deliberately act against the law, acts that harm others. Moreover, by the state officials who have been given the duty to administer the registration of land, officials are not thorough in reviewing the correctness of the data object registered land. Therefore, the government and state officials should better prepare a better registration system, based on the principles and spirit of the law itself in order to ensure the rights of all components of society in order to create an objective law itself

- for the Applicant. For the applicant himself in the submission of property rights must first re-examine the land objects to be submitted, whether the land is the object of the dispute or not, as well as looking back completeness requirements posed whether it is complete or still to be fulfilled, so that in the process of implementation of the petition may be running smoothly without a hitch.

\section{Bibliography}

[1] Indonesia Legal Center Publishing,2013, Hak-hak Atas Tanah, Jakarta

[2] Boedi Harsono, 1994, Hukum Agraria Indonesia, Jilid I, Djambatan, Jakarta

[3] Wawan Muhwan Hariri, 2011, Hukum Perikatan Dilengkapi Hukum Perikatan Dalam Islam, Pustaka Setia, Bandung 